DOI: 10.5613/rzs.42.1.5 Deala koji je uveo mjere socijalne si-

\section{Paul Krugman}

\section{Savjest liberala}

Zagreb: Algoritam, 2010, 271 str.

Iako je američki nobelovac Paul Krugman ekonomist, njegova knjiga Savjest liberala sociološki je intrigantna, a po temama koje analizira i izrazito aktualna. Krugman današnju ekonomsku krizu i fenomen dohodovne nejednakosti, kojima se u knjizi primarno bavi, promatra kao izravne posljedice promjene društvenih vrijednosti i političkih okolnosti, a ne kao nužne posljedice ekonomske globalizacije ili drugih ekonomskih procesa. Osim teorijsko-analitičke dimenzije, knjiga predstavlja i svojevrsni manifest angažiranog intelektualca, što je vidljivo i iz samoga naslova.

$\mathrm{U}$ predgovoru Krugman oslikava aktualni američki društveno-ekonomski kontekst tvrdeći da se današnja ekonomska kriza može objasniti nedovoljno reguliranim financijskim sustavom čiji je nastanak izravna posljedica konzervativne političke i ekonomske filozofije. Naznačujući sadašnje i buduće promjene političkog raspoloženja u SAD-u, Krugman smatra da je današnja Amerika spremna za novi New Deal.

U prvom poglavlju Krugman napominje da je poslijeratno američko društvo bilo obilježeno ekonomskom jednakošću koja je bila posljedica New gurnosti, povećao poreze bogatima i jače regulirao financijske institucije. Sve se promijenilo usponom konzervativne politike krajem 70-ih, ekonomske se nejednakosti produbljuju, a politička polarizacija između demokrata i konzervativaca naglo se povećava. Krugman stoga u modernoj američkoj povijesti vidi dva luka - onaj ekonomski koji ide od velike nejednakosti preko jednakosti i natrag, te onaj politički od krajnje stranačke polarizacije do suradnje i natrag.

Krugman smatra da je odlučujuća bila politička odluka da se ide u korist najbogatijima i tako promijeni distribucija dohotka. Takva politička odluka operacionalizirana je napadom na sindikalni pokret, smanjenjem poreznih stopa imućnijima te smanjenjem socijalnih ograničenja porasta menadžerskih plaća. Porast jednakosti u doba i nakon New Deala bio je nagao, što znači da su u njegovu nastanku političke odluke i vrijednosno-normativne promjene bile važnije od ekonomskih procesa. Zatim, do porasta ekonomske nejednakosti 80ih došlo je nakon nastanka projekta konzervativizma, a ne prije njih. Treće, tehnološke promjene teško mogu biti glavni uzrok povećanja nejednakosti jer se u razdoblju nakon 80 -ih dohodak obrazovanih Amerikanaca nije znatnije povećao.

U drugom poglavlju Krugman opisuje ono što naziva Dugo pozlaćeno 
doba (od 1870-ih do New Deala). Veliki dobitnici toga vremena bili su industrijski magnati i financijaši. Njihovi su dobitci uglavnom bili posljedica male pregovaračke moći radništva - radničko organiziranje bilo je suzbijano, a štrajkovi često slamani i od strane države. Nesudjelovanje znatnijeg dijela radništva u političkom procesu, kao i moćni financijski interesi, izborna prijevara te društvene podjele onemogućili su promjene.

Treće poglavlje započinje Krugmanovim retoričkim pitanjem - jesu li velike ekonomske nejednakosti doista posljedica tržišnih sila? Prema Kuznetsovoj krivulji raspodjela dohotka determinirana je tržišnim silama, a određuju je ponuda i potražnja za faktorima proizvodnje. U početnim fazama razvoja rad je obilan, a kapital rijedak, a to se onda odražava i u većim dohodcima od kapitala. U kasnijim fazama presušuju izvori radne snage, a kapital zbog povećanog dohotka i štednje postaje obilnijim. Logična je posljedica povećana jednakost, tj. smanjenje kapitalnih dobitaka i povećanje nadnica. Prema Krugmanu, Kuznetsova krivulja ne može objasniti naglo smanjenje dohodovnih nejednakosti nakon New Deala te ispravno objašnjenje nalazi u porezima. Naime, porezne stope za najbogatije višestruko rastu, a izrazito se povećavaju i korporativni porezi i porezi na nasljedstvo.

$\mathrm{U}$ četvrtom poglavlju Krugman lako prihvaćanje postignuća socijalne države objašnjava s pomoću nekoliko čimbenika. Prvi je konzervativizam američkoga biračkog tijela, koje teži zadržati dotadašnje stanje stvari. Postignuća New Deala i ratno reguliranje eliminirali su strah populacije od državnog miješanja u ekonomiju. Drugi su važan razlog prihvaćanja socijalne države demografske promjene. Naturalizacija imigranata povećala je biračko tijelo interesno usmjereno demokratima i većoj društvenoj jednakosti. Treći je razlog jak sindikalni pokret. Sindikati, $\mathrm{u}$ koje je u to doba bila učlanjena trećina američkih radnika, mobilizirali su radništvo na glasanje, što je pogodovalo uspjehu Demokratske stranke.

Šezdesete su godine (peto poglavlje) donijele povećanje životnog standarda Amerikanaca u usporedbi s prethodnim generacijama. No istodobno su se dogodile i društvene promjene koje su pripremile teren za kasniji uspon konzervativnog projekta. Porast kriminala i ulični nemiri, kontrakulturni pokreti i Vijetnamski rat kod građana su pojačali percepciju da se zemlja kreće prema kaosu i raspadu. Širenje socijalne države počinje dovoditi i do »sindroma socijalne pomoći«, tj. uvjerenja da se socijalne beneficije (pre)široko koriste. Urbani nemiri i porast kriminala doveli su do jačeg inzistiranja na važnost jake vlasti i poštovanja autoriteta, a liberalni se svjetonazor sve više počinje kriviti za smanjenje vladavine zakona.

U šestom poglavlju Krugman opisuje projekt konzervativizma kao produkt koalicije između poslovnih interesa i konzervativnih intelektualaca. Otpor socijalnoj državi najprije se pojavljuje kod malih i srednjih posloda- 
vaca kojima visoke nadnice i sindikalna moć donose gubitke. Intelektualnu bazu najprije čine čikaški ekonomisti, kritičari keynesovske ekonomije, te sociolozi okupljeni oko časopisa The Public Interest. Kod ekonomista se ponovno pojavljuje tržišni fundamentalizam i vjera u »nevidljivu ruku« koja se protivi državnoj intervenciji. Sociolozi su uglavnom kritizirali slom društvenog poretka i zlouporabe socijalne države.

U sedmom poglavlju Krugman pokazuje da su dobitci rasta nacionalnog dohotka neravnomjerno raspodijeljeni - najveći su dobitnici pojedinci iznad 90-og percentila, tj. najimućniji. Standardno ekonomsko objašnjenje tih nejednakosti naziva se SBTC (skill-based technical change), a u osnovi se sastoji od tvrdnje da današnja ekonomija zahtijeva visokoobrazovane pojedince obučene za korištenje novih tehnologija, što izaziva dohodovni jaz između onih koji njima vladaju i onih koji to nisu u stanju. Nasuprot tomu, Krugman objašnjenje nejednakosti nalazi u političkim promjenama, institucionalnim promjenama (pad sindikalne moći), kao i u promjenama društvenih normi, tj. porastu menadžerskih plaća - više se ne vjeruje da je za radni moral loše da menadžeri zarađuju puno više od radnika.

U osmom poglavlju Krugman srž konzervativnog projekta pronalazi u poreznoj politici kojom se favoriziraju najbogatiji. Reagan je tako nakon dolaska na vlast smanjio poreze najbogatijima, a smanjio je i porezne stope na kapitalnu dobit. G. W. Bush dvaput je smanjivao poreze, prvi put poreze na dohodak i na nasljedstvo najbogatijih, a drugi put poreze na kapitalnu dobit. Bushovo razdoblje obilježava i pokušaj jače privatizacije zdravstva. Clinton je, s druge strane, povećavao poreze najbogatijim, uključujući i ukidanje gornjeg limita za Medicare. Stoga se, prema Krugmanu, doista može reći da se republikanska i demokratska politika izrazito razlikuju.

Krugman deveto poglavlje započinje pitanjem kako to da jedan dio američkoga radničkog biračkog tijela ne glasuje u skladu s vlastitim interesom? Prema Krugmanu, odgovor se krije u republikanskoj promjeni tema, »masovnoj distrakciji« kojom se eksploatiraju druga pitanja kako bi se skrenula pozornost s mjera koje povećavaju nejednakost. Najvažnije su takve teme rasno pitanje, vanjska politika i vrijednosti tradicionalnog morala.

U desetom poglavlju Krugman uglavnom rezimira argumente zbog kojih smatra da je sazrelo vrijeme za novu politiku jednakosti. Oni se uglavnom odnose na povećanje zabrinutosti zbog ekonomske situacije i nejednakosti, neuspjeha u vanjskoj politici, kao i naznake slabljenja rasnih podjela.

Krugman jedanaesto poglavlje započinje konstatacijom da SAD nema zajamčenu zdravstvenu zaštitu svojih stanovnika, pri čemu Amerikanci za zdravstvo izdvajaju veći dio nacionalnoga dohotka od ostalih razvijenih zemalja. Kako bi opstala na tržištu, privatna osiguranja nastoje selekcionirati klijente prema zdravstvenom statusu i naplatiti više premije onima koji će 
se vjerojatnije razboljeti, a u slučaju bolesti svim silama nastoje ne isplatiti naknade. To dovodi do golemih troškova dokazivanja (ne)opravdanosti isplate, kao i do velikih troškova procjene potencijalne rizičnosti osiguranika. Unatoč svim pokazateljima neučinkovitosti, opće zdravstveno osiguranje nije uvedeno zbog konzervativne politike državnog nemiješanja te otpora privatnih osiguranja i farmaceutske industrije, koji bi u slučaju njegova uvođenja najviše izgubili.

Dvanaesto poglavlje bavi se širim kontekstom važnosti smanjenja društvenih nejednakosti. Američko samopoimanje oduvijek je obilježeno vjerom u nepostojanje prevelikih razlika između onih koji imaju i onih koji nemaju. Goleme dohodovne nejednakosti osim osjećaja frustracije izazivaju i šire negativne ekonomske posljedice. Pokušaj srednje klase da zadrži životni standard i svojoj djeci pruži sve više može odvesti u prekomjerno zaduživanje i nestabilnost financijskog sustava.

U završnom poglavlju Krugman se zalaže za osiguravanje demokracije i građanskih sloboda, uz smanjenje ekstremnih razlika u imovinskom statusu. Novi New Deal građane treba zaštititi od rizika i smanjiti nesigurnost. Prema Krugmanu, u budućnosti bi razlike između stranaka opet trebale biti smanjene, a konsenzus oko osnovnih društvenih i političkih ciljeva nadopunjen demokratskom utakmicom.

Govoreći ponajviše o američkom društvu, Krugman u osnovi nudi sociološki pristup gospodarskoj stvarnosti, jer ekonomsko-tehničku analizu pojedinih fenomena nadopunjuje naglašavanjem važnosti »mekih« varijabli poput promjena vrijednosti, normi, odnosa političke moći i odnosa među društvenim skupinama (klasama, rasama, etničkim skupinama...) i sl. Zbog tih razloga ova knjiga, pomalo neočekivano, predstavlja izvrstan doprinos suvremenoj ekonomskoj sociologiji.

\author{
Željko Pavić \\ Odjel za kulturologiju, \\ Sveučilište J. J. Strossmayera \\ u Osijeku
}

DOI: $10.5613 /$ rzs.42.1.6

\section{Zygmunt Bauman \\ Tekuća modernost}

Zagreb: Naklada Pelago, 2011, 223 str.

Jedanaest godina nakon objavljivanja izvornika knjige Tekuća modernost Zygmunta Baumana, uglednoga profesora emeritusa Sveučilišta u Leedsu, autora s više od šezdeset monografija na engleskom i poljskom jeziku i sociološkog autoriteta svjetske reputacije, pojavljuje se i hrvatski prijevod. U pet poglavlja ove knjige Zygmunt Bauman obrađuje pet tema: emancipaciju, individualnost, vrijeme/prostor, $\operatorname{rad} \mathrm{i}$ zajednicu. Sve su teme konceptualno sjedinjene tezom kako živimo u vremenu tekuće modernosti, bitno različitom 